\title{
Variation in transnationalism among Eastern European migrants in Italy: The role of duration of residence and integration
}

\author{
Eralba Cela ${ }^{\mathrm{a} 1}$, Tineke Fokkema ${ }^{\mathrm{b}}$ and Elena Ambrosetti ${ }^{\mathrm{c}}$ \\ a Department of Economics and Social Sciences, Polytechnic University of Marche, \\ Ancona, Italy; ${ }^{\mathrm{b}}$ Netherlands Interdisciplinary Demographic Institute (NIDI), The \\ Hague, Netherlands; ${ }^{\circ}$ Department of Methods and Models for Economics, Territory \\ and Finance, Sapienza University, Rome, Italy
}

(received 15 August 2012; final version received 25 October 2012)

Transnationalism of first-generation migrants, usually considered as a core element of their migratory projects, is nowadays taken somewhat for granted. Our aim in this paper is to examine empirically the relations of transnationalism with duration of residence and integration of Eastern European migrants in Italy, a country which evolved into a mass immigration country since the 1980s. Data come from the Integrometro survey 2008-2009, encompassing more than 4500 Eastern European migrants. We chose this group of migrants because East Europeans now constitute half of the foreign population in Italy and these nationalities have been overlooked by migration research on transnational topics. Our results show a positive relationship between migrants' economic integration and transnationalism, suggesting that economic resources facilitate the maintenance and development of cross-border ties. Being more integrated socioculturally, however, is accompanied with weaker transnational practices. Moreover, the level of transnational behaviour decreases the more years Eastern European migrants spend in Italy, which cannot be fully attributed to a higher level of socio-cultural integration.

Keywords: migration; transnationalism; integration; Eastern Europe; Italy

\footnotetext{
${ }^{1}$ Corresponding author. Email: e.cela@univpm.it
} 


\section{Introduction}

In the aftermath of the oil crisis of 1973, Northern European countries, the main destinations of immigration in Europe during the early postwar decades, adopted restrictive immigration policies. Labour migration was no longer encouraged, although migration flows to Northern Europe did not stop because of family reunification and family formation. The direction of labour migration, however, diverted to Southern European countries, characterized thus far by emigration and transit migration, but not by legislation on immigration, thereby facilitating migrants' efforts to enter into Southern Europe and transform it into a region of final destination.

It is not surprising that Southern European countries attracted large numbers of immigrants. Their economies are characterized by a segmented labour market, widespread small-scale family enterprises that often are labour (not capital) intensive, an increasing education of native population who refuse to engage in low-paid employment in agricultural, construction and low-skilled service sector jobs, a widespread informal economy especially in the tertiary sector such as tourism and domestic and care services, as well as by important seasonal sectors like agriculture, fishing and tourism. These labour niches require a low-cost labour force to survive and to compete within the global economy. All these aspects contributed to affect migrants' trajectories, shaping a new map of European immigration (King 2002).

The new waves of migrants are no longer solely attracted by pull factors such as production. Instead, a variety of motivations are at play depending both on push factors and migrants' own characteristics as well as on the specific socio-economic environment of the destination countries, resulting in diversification of migration types. King (2000) has defined a 'Southern European Model of Migration'; he describes the immigration phenomenon in the northern Mediterranean Basin as characterized by features such as the globalization of origins (broad range of nationalities), increased proportion of women as independent migrants from specific countries, the spreading of migration into both urban and rural areas, the presence of some skilled migrants from wealthy families, and high levels of irregular migration.

Among Southern European countries, Italy represents a singular case for the intensity of migration flows and the presence of a wide variety of nationalities. The first migrants were mainly men from Muslim countries like Tunisia, Morocco and Senegal, political refugees from Vietnam and Chile, students from Iran and Greece, 
and mostly females from Catholic origins like the Philippines and Cape Verde. Since the 1990s, after the fall of the Berlin Wall and the end of the communist regimes in Eastern Europe, Italy experienced a renewed boom in migration, characterized by different waves. The first migrants arrived at the beginning of the 1990s from Albania, followed by migrants from former Yugoslavia and Poland. Intensive flows from other Eastern European countries to Italy started in the early 2000s, in particular from Romania, Ukraine and Moldova.

Migration has thus become a structural element of Italian society. In the last ten years, the migrant population in Italy has more than tripled, passing from 1.3 million individuals reported in 2001 census, to 4.6 million at the end of 2010 , more than $7 \%$ of total population, according to the National Institute of Statistics (ISTAT). Since 2007 the increase in immigrant stocks is largely attributed to flows of Eastern European citizens. Currently, Eastern Europeans (Romanians and Albanians) and Northern Africans (Moroccans) are the largest national-origin communities in Italy, followed by Far Eastern Asians (Chinese and Filipinos).

Although migration from Eastern Europe has been characterized by several waves, as described above, the migration motives are largely similar - i.e. the quest for job opportunities and escape from political and economic crisis. Nevertheless, each community is characterized by some specific features that are reflected in its sex and age composition. Romanian migration was at the beginning male-dominated, employed in the construction and secondary sectors; later on it was followed by female migrants employed in the (health and child) care sector. The current sex ratio of Romanians in Italy is 86 males per 100 females. Albanians are the second community of foreign residents in Italy. The migration flows from Albania to Italy were for a long time dominated by male temporary labour migration. Thanks to family reunification, however, Albanian residents in Italy have nowadays a sex ratio of 118 males per 100 females. Migrants from Moldova, Poland and Ukraine are essentially females, working in the care sector. Consequently, the ratio of males to females in these populations is low, respectively 52,42 and 26 .

The emergence of these mostly female communities from Eastern Europe has attracted scholarly attention into the multiple relations they maintain with their countries of origin. So far, the focus has particularly been on mothering practices at distance and conjugal relationships (Ambrosini 2005; Banfi and Boccagni 2011; Castagnone et al. 2007; Catanzaro and Colombo 2009; Vlase 2006). In addition, 
some studies have been conducted on both their integration patterns in Italy and their ties with relatives left behind (Ban 2009; Cela and Moretti 2011; King and Mai 2008). These studies, however, are almost exclusively qualitative in nature and restricted to one of the main communities, like Romanians, Albanians, Ukrainians or Poles. Accordingly, there is a lack of quantitative research on the prevalence and determinants of transnational relations across all migrants from Eastern Europe in Italy. Hence, this study examines the transnational behaviour among first-generation Eastern European migrants in Italy, with a special focus on the relationship between transnationalism on the one hand, and duration of residence and integration on the other hand. Data come from a unique dataset, the Integrometro survey, carried out at the Italian national scale between 2008 and 2009.

\section{Interlinkages between duration of residence, integration and transnationalism}

For a long time, migrants were assumed to assimilate inevitably over time. The classical assimilation theory argued rather convincingly that the longer migrants stay in the host society, the more they will be integrated and the less they will remain connected to their home country (Alba 1985; Alba and Nee 1997; Gordon 1964). A major shift of thinking occurred since the introduction of the concept of transnationalism into the migration debate in the 1990s, transnationalism being defined as the process 'by which immigrants build social fields that link together their country of origin and their country of settlement' (Glick Schiller, Basch and BlancSzanton 2006). The emerging transnational perspective pushed researchers to move beyond the study of migrants' process of integration in the host society and to focus also on migrants' multiple ties with their country of origin (Guarnizo, Portes and Haller 2003; Portes and Rumbaut 2001; Portes and Zhou 1999). More particularly, it has challenged migration scholars to think more deeply and creatively about the linkages between duration of residence and integration on the one hand and transnationalism on the other hand. As a result, segmented assimilation theory emphasizes the importance of individual and contextual factors in determining the degree of integration and, contrary to the classic assimilation assumption, does not consider any more the ties with the home country as a barrier to integration processes (Basch, Glick Schiller and Blanc-Szanton 1994; Faist 2000; Glick Schiller, Basch and BlancSzanton 1992; Itzigsohn et al. 1999; Kivisto 2001; Levitt 2001; Portes, Guarnizo and Landolt 1999). 
To represent the broad range of transnational practices and to make the complexity of the relationship between transnationalism and integration more manageable, a number of researchers have identified typologies of transnationalism. For sure, the issue of time (duration of residence in the host society) is a key feature in understanding the evolution of transnational behaviour. Faist (2000), for instance, distinguishes three different typologies of transnational spaces. Firstly, there are transnational kinship groups, characterized by short-lived transnationalism and assimilation as time goes by, due to family reunification and/or death of firstgeneration migrants. The underlying assumption of this typology is a positive relationship between duration of residence and integration and a negative relationship of duration of residence and integration with transnationalism. Secondly come transnational circuits, typical in cross-border trading networks, characterized by mutual obligations among actors involved. In this second typology, we find the assumption of positive relationships between duration of residence, integration and transnationalism. Finally, transnational communities, such as diasporas or village communities, are characterized by enduring ties over time between migrants abroad and those staying behind; no relationship is assumed between duration of residence and integration on the one hand and transnationalism on the other hand.

Itzigsohn and Saucedo (2002), in the attempt to analyze incorporation and socio-cultural transnationalism, also identify three forms of transnationalism. The linear form suggests that, as time passes, incorporation increases and transnationalism slowly decreases. This assumes a positive relation between duration of residence and integration into the host society, and a negative one between residence/integration and transnationalism. Second, resource dependent transnationalism implies that time and financial resources are necessary to engage in cross-border practices and hence, assuming thereby a positive relationship between duration of residence, integration and transnationalism. Thirdly, reactive transnationalism results from discrimination or a negative experience of integration that migrants face in the host society. Therefore, a positive relationship between duration of residence, exclusion (negative integration) and transnationalism is assumed.

The research on the relationship between migrants' transnationalism and integration has found mixed findings rather than evidence conclusively pointing in any particular direction. Some studies support the idea that integration and 
transnational ties are not necessarily substitutes, but can be complements, in particular in the case of economic integration (Fokkema et al. 2012; Guarnizo, Portes and Haller 2003; Itzigsohn and Saucedo 2002; Landolt, Autler and Baires 1999; Popkin 1999; Portes, Haller and Guarnizo 2002; Sana 2005; Van Dalen, Groenewold and Fokkema 2005). Other scholars do not agree with the assumed positive relation between migrants' integration and transnationalism (Basch, Glick Schiller and BlancSzanton 1994; Faist 2000; Portes 1997). Only a few studies have focused on 'how transnational practices change over time or the extent to which they remain salient beyond the first generation' (Levitt 2001, 196).

Despite the large number of studies investigating the transnational lives of migrants, there is still a dearth of research on migrants' strength of ties and types of transnational activities, and more particularly on links with duration of residence and the integration process into the host society. Firstly, the majority of existing studies on transnationalism have been qualitative in nature and mostly focused on specific aspects of transnational lives among a particular migrant group; there is a lack of quantitative studies analyzing the overall level of transnationalism across migrant groups and its links with factors like duration of residence and integration. Secondly, most of the previous studies have been conducted in the United States. Consequently, the transnational behaviour of migrants in Europe is less documented. Finally, as far as European studies are concerned, the attention is almost exclusively focused on the longer-established migration groups (e.g. Moroccans and Turks) rather than on the more recent ones, like those from Central and Eastern Europe; and there are surprisingly few comparative empirical studies across different migrant groups (Fibbi and D'Amato 2008).

This study addresses these gaps by examining empirically the strength of transnational ties among Eastern European migrants in Italy and how these ties vary by duration of residence and level of integration into Italian society. As alternative and competing hypotheses are possible regarding the relationships between duration of residence, integration and transnationalism, the study will be explorative in nature; no specific hypotheses have been formulated beforehand.

\section{Data, methods and measures}

The data stem from the aforementioned Integrometro survey, administered in 32 provinces and towns across Italy, selected according to the high incidence of 
migrants and their diversification in relation to the socio-economic context. Respondents were selected using the 'aggregation center sampling technique' (Baio, Blangiardo and Blangiardo 2001), which is a suitable method for taking into account both legal and illegal migrants. This methodology has two steps. The first one is a random selection of those places that are frequently visited by migrants from developing countries. The underlying assumption is that in each area migrants are considered as a set of statistical units, that for daily activities necessarily need a number of contacts with certain locales or 'aggregation places' that can be official or unofficial (hospital, church, café, associations, malls, phone centres, etc.). In the second step migrants were selected random for the face-to-face interview. Measures were taken in order to avoid distortion in the sampling caused by the probability of a migrant being present in more than one centre.

The aim of the survey was to gain insight into the degree of migrants' integration into Italian society (Cesareo and Blangiardo 2009). In all cities, an identical questionnaire was used, which made it possible to pool the datasets. The survey collected information on a total sample of 12,047 individuals aged between 18 and 71 years old, representing 128 different nationalities, with different religions and different types of migration, both in terms of socio-economic position and in terms of migration waves. For the purpose of our analyses, the dataset is reduced to $N=3,484$ individuals from Eastern European countries.

\section{Dependent variable}

The key dependent variable is transnationalism. The Integrometro survey contains various indicators that are generally used to measure migrants' level of transnationalism (e.g. Beauchemin, Lagrange and Safi 2011; Fokkema et al. 2012; Kasinitz et al. 2008). As our focus is on transnational behaviour per se rather than on each transnational indicator individually, we carried out a Principal Components Analysis (PCA) with varimax rotation. This analysis extracted one factor, with an eigenvalue of 1.91 and explaining $48 \%$ of the total variance, using the following indicators: (1) remitting, based on the question 'Do you ever send money to your country of origin?' with the answer categories $0=$ no never, 1=yes, whenever I can and when there is a need, and $2=$ yes, regularly; (2) return intention, proxied by the question 'Do you intend to settle in Italy?' with the answer categories $0=$ forever, $1=$ for a long period, 2=don't know, and 3=for a short period; (3) feelings of belonging to the 
country of origin, running from $0=$ not at all to $3=$ very much; and (4) interest in the country of origin, i.e. the extent to which one wants to know what happens in their home country, running from $0=$ not at all to $3=$ very much. Table 1 shows the factor loadings, i.e. the correlation of each of these four transnationalism indicators with the extracted factor. All factor loadings are above 0.50, indicating that our chosen indicators strongly determine transnational behaviour. Based on the factor loadings, each respondent was assigned a transnational score (regression scoring coefficients, see Table 1, were used to calculate the score). After standardizing this to mean 'zero' and standard deviation 'one', we use the transnational score as the dependent variable in the multivariate regression model. The interpretation of the transnational score is as follows: the higher the score, the higher the respondent's level of transnational behaviour.

$<$ Table 1 about here >

\section{Key independent variables}

We operationalised two key independent variables: duration of residence and integration. The respondent's duration of residence refers to the length of time (in years) one lives in Italy, measured by the difference between the year of interview and the year at arrival. As regards integration, the Integrometro survey included a series of questions aimed at capturing respondents' integration into Italian society: (1) educational attainment, i.e. the highest level of education an individual has completed; (2) employment status, distinguishing between $0=$ out of the labour force (retired, disabled, housewives, students), 1=employed with an unstable labour

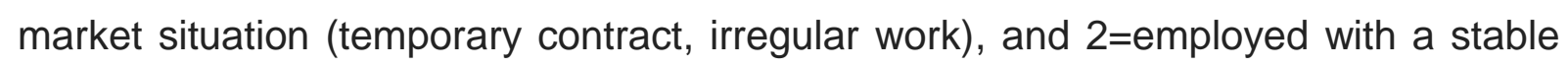
labour market position (permanent contract, own business); (3) perceived economic condition of the family, with the answer categories $0=$ 'we have difficulties to make ends meets', 1='we spend everything we earn', and 2='we manage to save something'; ${ }^{1}$ (4) self-reported Italian-speaking proficiency, running from $0=$ not at all to 4=very well; (5) ethnic composition of respondent's friends, with the answer categories $0=$ only non-natives, $1=$ more non-natives than Italians, $2=$ both, and $3=$ more Italians than non-natives; (6) sympathy for the Italian lifestyle, running from $0=$ not at all to $1=$ very much; ${ }^{2}$ (7) acceptance of exogamous marriage, i.e. the level of agreement with the statement 'In case your daughter were to marry an Italian man, to 
what extent would you approve this marriage?', running from $0=$ not at all to $3=$ very much; (8) feelings of belonging to Italy, running from $0=$ not at all to $3=$ very strong; and (9) interest in Italy, i.e. the extent to which one wants to know what happens in Italy, running from $0=$ not at all to $3=$ very much. To obtain a reduced set of variables representing integration, we ran a Principal Components Analysis with varimax rotation on these indicators. The PCA identified two factors, with an eigenvalue of 2.51 and 1.29 and explaining 28 and $14 \%$ of the total variance, respectively (Table 2). The first factor mainly captures the non-economic indicators (4-9 in the above list) and is therefore referred to as 'socio-cultural integration'; whereas the second factor, labelled the 'economic integration', is highly loaded on the economic indicators 'employment status', 'perceived economic condition of the family' and, to a lesser extent, 'educational attainment'. ${ }^{3}$ Following the same process as for the dependent variable transnationalism, an individual socio-cultural with respect to economic integration score was calculated: the higher the score, the greater the respondent's degree of socio-cultural vis-à-vis economic integration.

$<$ Table 2 about here $>$

\section{Control variables}

Finally, we included the following control variables in the analyses: (1) respondent's age at arrival (measured in years); (2) gender, represented by the dummy variable man; (3) partner status, using two dummy variables comparing individuals with a same-ethnicity partner and those with a partner of a different ethnic background, respectively, to unpartnered individuals; (4) parent status, using two dummy variables comparing parents whose children are all living in Italy and parents with one or more children living abroad, respectively, to those without children; (5) religion, using a series of dummy-coded variables comparing Muslims, Orthodox Christians, Catholics and those with another religion, respectively, to non-religious individuals; and (6) country of origin, distinguishing the main emigration countries in the Integrometro survey ( $5 \%$ or more of the total Eastern European migrant population sample) Romania, Albania, Ukraine, Moldova and Poland - from the other Eastern European countries. Table 3 provides descriptive information on all variables used in the analyses. 
$<$ Table 3 about here $>$

\section{Results}

To examine the impact of duration of residence and integration on the transnational behaviour of first-generation Eastern European migrants, stepwise multiple regression analyses were carried out. Models 1,2 and 3 sequentially include the control variables, the duration of residence variable, and the socio-cultural and economic integration factors. The results of these analyses are presented in Table 4.

\section{Basic model}

Looking first at the control variables in Model 1, age at arrival has the expected positive impact on transnationalism. The effect is linear; additional analysis showed a non-significant effect of the squared age at arrival. Thus, the younger the respondents were at the time of their move to Italy, the less they were oriented towards their country of birth at the time of the interview. Respondents' gender also emerges as a significant predictor: men report higher transnational scores than their female counterparts. With regard to the partner status, it is not so much the fact of having a partner that affects transnational behaviour, but the ethnicity of one's partner. Compared with their single counterparts, respondents whose partner is of the same ethnicity exhibit a higher intensity of transnational practices; no differences in transnationalism scores are found between those with an exogamous relationship and those without a partner. Being a parent coupled with the residence of one's children is significantly associated with the level of transnational engagement. Parents whose children are all living in Italy are less transnationally engaged than their childless counterparts, whereas transnational practices are more frequent among parents who have one or more children living abroad, presumably in the home country. The latter is likely to be an 'automatic' effect of exposure: migrants whose children are in the country of birth have more opportunities and responsibilities to be involved in transnational relations, to travel to the country of origin, and to maintain various linkages with the country of origin (Beauchemin, Lagrange and Safi 2011). Respondents' denomination has an effect on transnationalism as well. Compared to those who identify themselves as non-religious, Muslims, Orthodox Christians and Catholics all report higher transnational scores (though with decreasing levels of statistical significance in that order); those with another religion 
do not diverge from the non-religious ones. Finally, the level of transnationalism is found to be linked with respondent's origin for those born in Poland and Ukraine.

\section{Duration of residence}

Model 2 shows that duration of residence has a significantly negative effect on transnationalism: the more years living in Italy, the lower the level of transnationalism. Additional analysis suggests that this effect is more or less linear: the coefficient of the square of the duration of residence is negative but not significant.

Introduction of the duration of residence variable leads to an increase of the explained variance from 15.6 to $17.4 \%$, and hardly affects the direction and significance of the effect of the control variables. The only exception is that the previously observed strong effects of having a same-ethnicity partner (positive) and children living in Italy (negative) lose strength substantially, although both effects retain statistical significance.

\section{Integration}

Respondents' level of integration determines their engagement in transnational practices to a considerable extent, increasing the explained variance in Model 3 by a further $8.0 \%$. The effect directions of socio-cultural and economic integration, however, are each other's opposite: the transnational score decreases significantly in proportion to level of socio-cultural integration, while a positive association is observed between level of economic integration and transnational engagement. Moreover, the strength of the positive impact of economic integration on transnational engagement, though significant, is modest compared to that of the negative influence of socio-cultural integration. All else equal, the transnational score decreases by about three-tenths of a standard deviation with each standard deviation increase in the socio-cultural integration factor score.

Once the economic and socio-cultural integration variables are taken into account, no significant differences are found anymore between the distinctive migrant groups. Additional analyses show that the relatively high transnational score of the Polish migrants is mainly the result of their low level of socio-cultural integration into Italian society, while both the high level of socio-cultural integration and the low level of economic integration are attributable to the relatively high level of transnational engagement among those born in Ukraine. Furthermore, the previously observed 
positive effects of being a man and having a same-ethnicity partner become insignificant, as do the negative effect of having children who all live in Italy. In addition, the above-average level of transnational engagement among Muslims reduces substantially once integration is taken into account, although the difference between Muslims and non-religious respondents is still significant. The most relevant finding, however, is the persistent negative effect of duration of residence on transnational behaviour, suggesting that the relation cannot be explained exclusively by a higher level of socio-cultural integration over time. Overall, the variables included in the regression analyses explain $25.4 \%$ of the variance in the level of transnational engagement.

$<$ Table 4 about here >

\section{Conclusions}

The aim of our paper was to examine empirically the strength of transnational ties among Eastern European migrants in Italy, and more specifically how these ties vary by migrants' duration of residence and level integration into Italian society. We pursued this goal through analyses of Integrometro survey data on migrants in Italy and focused on transnational behaviour in the round rather than on each transnational indicator individually. As alternative and competing hypotheses are possible regarding the relationships between duration of residence, integration and transnationalism, the study was explorative in nature.

Immigrants' transnationalism and integration are hot topics both in the political and academic debate. Although they represent two sides of one phenomenon migration - maintaining transnational ties is sometimes considered either to impede the integration of migrants or to be a reaction to experiences of exclusion (negative integration) and discrimination. This was partly confirmed by our study: a strong negative association is observed between Eastern European migrants' level of sociocultural integration and their transnational engagement. However, in accordance with several previous studies and the 'transnational circuits' and 'resource dependent' typologies of Faist (2000) and Itzigsohn and Saucedo (2002), respectively, there was a clear positive relationship of transnationalism with economic integration. The opposite directions of the effects of socio-cultural and economic integration suggest 
that only economic resources (both in terms of human capital and income) are helpful in maintaining and developing transnational ties, while being socio-culturally integrated in the host society weakens the ongoing relations with the countries of origin.

As pointed out by Guarnizo, Portes and Haller (2003) with regard to Colombians, Salvadorans and Dominicans in the US, the national origin and the context of exit and reception turned out to be relevant determinants of migrants' relations with home countries. This is the case of Poles and Ukrainians, although their effects on transnationalism are mediated by the level of integration.

Other individual characteristics that turned out to be associated with transnationalism, for a large part through the mediating role of integration, are gender and the ethnicity of the partner: males and those with a same-ethnicity partner are less integrated into Italian society, and hence more transnationally active. An explanation for the difference between men and women can be found in the different gender roles within their exit context: for many women migration represents both an escape route from patriarchal societies, unsuccessful marriages, domestic violence etc. and an empowerment path, thanks to the economic independence achieved. This process contributes to transforming their migratory projects into definitive settlement and hence to weaken the ties with their country of origin.

The findings of our study also revealed a number of individual characteristics that are associated with a high level of transnational engagement, regardless of their level of integration: older age at arriving (which can be a proxy for a higher number of relatives and friends left behind), the presence of children living abroad (that implies close family contacts in the home country and responsibilities and obligations towards them), and being Muslim/Orthodox/Catholic. On the last point, religion probably acts as a transnational institution that helps to keep alive and strengthen the community bonds in and towards Italy, as found in the ethnographic study of Cingolani (2007) on Romanians in Italy. Perhaps the most striking finding is the persistent negative relation of length of residence with transnationalism, that is not entirely attributed to a higher level of socio-cultural integration over time.

Our study, however, has some limitations; one of the most important is the missing information about the composition of the family and friends left back home. Further explanation of migrants' transnational behaviour could be found through a multi-sited investigation, not only quantitative, but also qualitative, carried out both in 
destination and origin settings. More in general, we think that although the emergence of a transnational perspective has enriched the study of international migration, much remains to be done, since many shortcomings play along with this perspective. Contrary to the study of remittances, for example, where conceptual and quantitative studies abound, the more social dimensions of transnational behaviour are somewhat bereft of concrete assumptions and hypotheses derived from theoretical frameworks; instead there is only a huge variety of empirical (mainly qualitative) evidence. Accordingly, systematic research on specific types of transnationalism, their magnitude and determinants is still missing. Future research on transnationalism has to challenge questions like how transnationalism is related to the process of migrants' integration in the receiving societies and to the duration of residence. Why do studies repeatedly find a negative relationship between sociocultural integration and transnationalism? And why is transnational engagement negatively associated with duration of residence, irrespective of one's level of integration? Probably the first step towards answering these kind of questions is to develop a theoretical framework and generate clear hypotheses that can act as a baseline for future studies.

\section{Notes}

${ }^{1}$ Personal income, the objective measurement of income available in the survey, was not included for two reasons: respondents' personal income variable was categorical, thus impeding the calculation of an exact income, and included many missing values.

2 The respondents were asked to what extent they are in favour of six lifestyle aspects of the Italians, namely the way they (a) raise their children; (b) work; (c) go through the family relationships, (d) dress; (e) spend their leisure time; and (f) their food. The response categories ranged from 'don't like at all (including don't have information about it)' to 'like it very much'. The scores on these six items were converted into one summary scale, reflecting the degree of sympathy for the Italian lifestyle.

${ }^{3}$ The rather low factor loading of educational attainment on economic integration is likely to be related to a severe mismatch between migrants' skills and jobs. This is a contextual factor due to the Italian legislation (and lack of bilateral agreements with origin countries) that does not recognize migrants' qualifications, resulting in their embeddedness in low-skilled and lowpaid jobs without possibility of upward mobility. At the same time, the factor loading of educational attainment on socio-cultural integration is rather high, which is not surprising given that highly educated people generally have a more secular and open worldview and 
that highly skilled migrants are likely to experience fewer class and attitudinal differences with native-born populations and to face less discrimination (Fokkema and De Haas 2011).

\section{References}

Alba, R. 1985. Italian Americans: Into the twilight of ethnicity. Englewood Cliffs, NJ: PrenticeHall.

Alba, R. and V. Nee. 1997. Rethinking assimilation theory for a new era of immigration. International Migration Review 31, no. 4: 826-75.

Ambrosini, M. 2005. Dentro il welfare invisibile: Aiutanti domiciliari immigrate e assistenza agli anziani [Inside the invisibile welfare. Immigrant helpers and elderly care]. Studi Emigrazione 42, no. 159: 561-95.

Baio, G., G. Blangiardo and M. Blangiardo. 2001. Center sampling technique in foreign migration surveys: A methodological note. Journal of Official Statistics 27, no. 4: 451-65.

Ban, C. 2009. Economic transnationalism and its ambiguities: The case of Romanian migration to Italy. International Migration 50, no. 6: 129-49.

Banfi, L. and Boccagni P. 2011. Transnational family life and female migration in Italy: One or multiple patterns? In Gender, generations and the family in international migration, ed. A. Kraler, E. Kofman, M. Kohli and C. Schmoll, 287-311. Amsterdam: Amsterdam University Press.

Basch, L., N. Glick Schiller and C. Blanc-Szanton. 1994. Nations unbound: Transnational projects, postcolonial predicaments, and deterritorialized nation-states. Langhorne, PA: Gordon and Breach.

Beauchemin, C., H. Lagrange and M. Safi. 2011. Transnationalism and immigrant assimilation in France: Between here and there? INED Documents de Travail 172.

Cesareo, V. and G. Blangiardo. 2009. Indici di integrazione: Un indagine empirica sulla realtà migratoria italiana [Integration indices: An empirical study in the Italian migratory context] . Milan: Franco Angeli.

Castagnone, E., M. Eve, E. Petrillo, F. Piperno and J. Chaloff. 2007. Madri migranti. La migrazione di cura dalla Romania e dall'Ucraina in Italia: Percorsi ed impatto sui paesi di origine [Migrant mothers. Care migration from Romania and Ukraine to Italy: Paths and impact on countries of origin], CeSPI Working Paper, http://www.cespi.it/WP/WP34\%20Madri\%20migranti.pdf (10/06/2011).

Catanzaro, R. and A. Colombo, eds. 2009. Badanti \& Co. Il lavoro domestico straniero in Italia [Badanti \& Co: Foreign domestic work in Italy]. Bologna: II Mulino.

Cela, E. and E. Moretti 2011. Le determinanti delle rimesse: Evidenze dalla comunità serba e albanese in Italia [Determinants of remittances: Evidence from Serbians and Albanians in Italy]. In Rimesse e migrazione: Ipotesi interpretative e verifiche empiriche [Remittances 
and migration: Interpretive hypotheses and empirical testing], ed. A. Arrighetti and A. Lasagni, 61-82. Milano: Franco Angeli.

Cingolani, P. 2007. Transnational communities in a globalized world: Romanians in Italy, FIERI Research Report, www.fieri.it/download.php?fileID=194\&lang=ita (10/06/2011).

Faist, T. 2000. Transnationalization in international migration: Implications for the study of citizenship and culture. Ethnic and Racial Studies 23, no. 2: 189-222.

Fibbi, R. and G. D'Amato. 2008. Transnationalisme des migrants en Europe: Une preuve par les faits. Revue Européenne des Migrations Internationales 24, no. 2: 7-22.

Fokkema, T. and H. de Haas. 2011. Pre- and post-migration determinants of socio-cultural integration of African immigrants in Italy and Spain. International Migration. doi:10.1111/j.1468-2435.2011.00687.x.

Fokkema, T., L. Lessard-Phillips , J.D. Bachmeier and S.K. Brown. 2012. The link between the transnational behaviour and integration of the second generation in European and American cities: Does the context of reception matter? Nordic Journal of Migration Research 2, no. 2: 111-23.

Glick Schiller, N., L. Basch and C. Blanc-Szanton. eds. 1992. Towards a transnational perspective on migration: Race, class, ethnicity, and nationalism reconsidered. New York: New York Academy of Sciences.

Glick Schiller, N., L. Basch and C. Blanc-Szanton. 2006. Transnationalism: A new analytic framework for understanding migration. Annals of the New York Academy of Sciences 645: 1-24.

Gordon, M.M. 1964. Assimilation in American life: The role of race, religion, and national origins. New York: Oxford University Press.

Guarnizo, L.E., A. Portes and W. Haller. 2003. Assimilation and transnationalism: Determinants of transnational political action among contemporary migrants. American Journal of Sociology 108, no. 6: 1211-48.

Itzigsohn, J., C. Dore Cabral, E. Hernandez Medina and O. Vazquez. 1999. Mapping Dominican transnationalism: Narrow and broad transnational practices. Ethnic and Racial Studies 22, no 2: 316-39.

Itzigsohn, J. and S.G. Saucedo. 2002. Immigrant incorporation and sociocultural transnationalism. International Migration Review 36, no. 3: 766-98.

Kasinitz P., J.H. Mollenkopf, M.C. Waters and J. Holdaway. 2008. Inheriting the city: The children of immigrants come of age. New York and Cambridge, Mass: Russell Sage Foundation and Harvard University Press.

King, R. 2000. Southern Europe in the changing global map of migration. In Eldorado or fortress? Migration in Southern Europe, ed. R. King, G. Lazaridis and C. Tsardanidis, 326. London: Palgrave Macmillan. 
King, R. 2002. Towards a new map of European migration. International Journal of Population Geography 8, no. 2: 89-106.

King, R. and N. Mai. 2008. Out of Albania: From crisis migration to social inclusion in Italy. Oxford: Berghahn.

Kivisto, P. 2001. Theorizing transnational immigration: A critical review of current efforts. Ethnic and Racial Studies 24, no. 4: 549-77.

Landolt, P., L. Autler and S. Baires. 1999. From 'Hermano Lejano' to 'Hermano Mayor': The dialectics of Salvadoran transnationalism. Ethnic and Racial Studies 22, no. 2: 290-315.

Levitt, P. 2001. The transnational villagers. Berkeley: University of California Press.

Popkin, E. 1999. Guatemalan Mayan migration to Los Angeles: Constructing transnational linkages in the context of the settlement process. Ethnic and Racial Studies 22, no. 2: 267-89.

Portes, A. 1997. Immigration theory for a new century: Some problems and opportunities. International Migration Review 31, no. 4: 799-825.

Portes, A., L.E. Guarnizo and I. Landolt. 1999. Introduction: Pitfalls and promise of an emergent research field. Ethnic and Racial Studies 22, no. 2: 217-37.

Portes, A. and G.R. Rumbaut. 2001. Legacies: The story of the immigrant second generation. Berkeley: University of California Press.

Portes, A. and M. Zhou. 1999. Entrepreneurship and economic progress in the 1990s: A comparative analysis of immigrants and African Americans. In Immigration and opportunity: Race, ethnicity, and employment in the United States, ed. F.D. Bean and S. Bell-Rose, 143-71. New York: Russell Sage Foundation.

Portes, A., W.J. Haller and L.E. Guarnizo. 2002. Transnational entrepreneurs: An alternative form of immigrant economic adaptation. American Sociological Review 67, no. 2: 278-98.

Sana, M. 2005. Buying membership in the transnational community: Migrant remittances, social status, and assimilation. Population Research and Policy Review 24, no. 3: 23161.

Van Dalen, H.P., G. Groenewold and T. Fokkema. 2005. The effect of remittances on emigration intentions in Egypt, Morocco, and Turkey. Population Studies 59, no. 3: 37592.

Vlase, I. 2006. Rumanian migrant women and housework in Italy. Studi Emigrazione 43, no. 161: 6-22. 
Table 1. Factor loadings and scoring coefficients for transnational behaviour ( $\mathrm{N}$ unweighted $=3,484$ )

Factor loadings Scoring coefficients

Remitting

$\begin{array}{ll}0.52 & 0.27 \\ 0.56 & 0.29 \\ 0.82 & 0.43 \\ 0.81 & 0.42\end{array}$

Return intention

0.42

Interest in country of origin

Source: Integrometro Survey

Table 2. Factor loadings and scoring coefficients for socio-cultural and economic integration (N-unweighted $=3,484$ )

\begin{tabular}{|c|c|c|c|c|}
\hline & \multicolumn{2}{|c|}{ Factor loadings } & \multicolumn{2}{|c|}{ Scoring coefficients } \\
\hline & Socio-cultural & Economic & Socio-cultural & Economic \\
\hline Educational attainment & 0.33 & 0.24 & 0.12 & 0.16 \\
\hline Employment status & 0.03 & 0.76 & -0.04 & 0.60 \\
\hline Perceived economic & & & & \\
\hline condition of the family & 0.00 & 0.79 & -0.06 & 0.62 \\
\hline Italian language profiency & 0.66 & 0.07 & 0.26 & 0.01 \\
\hline Ethnic composition of friends & 0.72 & -0.01 & 0.29 & -0.06 \\
\hline $\begin{array}{l}\text { Sympathy for Italian lifestyle } \\
\text { Aporoval of exoaamous }\end{array}$ & 0.55 & 0.02 & 0.22 & -0.02 \\
\hline marriage & 0.55 & -0.03 & 0.23 & -0.07 \\
\hline Feelings of belonging to Italy & 0.71 & -0.01 & 0.29 & -0.06 \\
\hline Interest in Italy & 0.58 & 0.17 & 0.22 & 0.09 \\
\hline
\end{tabular}

Source: Integrometro Survey 
Table 3. Descriptive statistics of the dependent and independent variables unweighted=3,484)

$\%$ Mean SD $\begin{aligned} & \text { Range } \\ & \text { Min Max }\end{aligned}$

\section{Transnationalism}

\section{Integration}

Socio-cultural

Economic

\section{Length of residence}

\section{Control variables}

\section{Age at arrival}

Man

Partner status (ref. no partner)

Partner, same ethnicity

Partner, other ethnicity

No partner

Parent status

Children, all in Italy

Children, one or more abroad

No children

Religion

Muslim

Orthodox

Catholic

Other

No religion

Country of origin

Romania

Albania

Ukraine

Moldova

Poland

Other Eastern European country

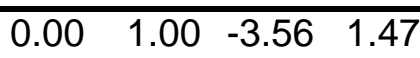

$\begin{array}{llll}0.00 & 1.00 & -3.36 & 2.28\end{array}$

$\begin{array}{llll}0.00 & 1.00 & -2.31 & 1.90\end{array}$

$7.35 \quad 4.65$

29.8510 .85

41.5

74.1

14.5

11.4

22.6

36.3

41.2

19.1

47.0

22.7

3.5

7.7

32.7

31.1

12.4

5.0

6.4

12.4

Source: Integrometro Survey 
Table 4. Determinants of the level of transnationalism among first-generation migrants from Eastern Europe (N-unweighted=3,484)

\begin{tabular}{|c|c|c|c|}
\hline Model: & 1 & 2 & 3 \\
\hline \multicolumn{4}{|l|}{ Control variables } \\
\hline Age at arrival & $0.02^{* \star *}$ & $0.01^{* * *}$ & $0.01^{* *}$ \\
\hline Man & $0.14^{\star *}$ & $0.16^{\star * *}$ & 0.08 \\
\hline \multicolumn{4}{|l|}{ Partner status (ref. no partner) } \\
\hline Partner, same ethnicity & $0.18^{* *}$ & $0.12^{*}$ & 0.10 \\
\hline Partner, other ethnicity & -0.10 & -0.10 & 0.02 \\
\hline \multicolumn{4}{|l|}{ Parent status (ref. no children) } \\
\hline Children, all in Italy & $-0.23^{* * *}$ & $-0.12^{*}$ & -0.07 \\
\hline Children, one or more abroad & $0.38^{* * *}$ & $0.43^{* * *}$ & $0.35^{\star * *}$ \\
\hline \multicolumn{4}{|l|}{ Religion (ref. no religion) } \\
\hline Muslim & $0.32^{\star \star *}$ & $0.28^{* \star *}$ & $0.18^{\star}$ \\
\hline Orthodox & $0.25^{\star *}$ & $0.22^{* *}$ & $0.19^{\star *}$ \\
\hline Catholic & $0.17^{\star}$ & $0.16^{*}$ & $0.16^{\star}$ \\
\hline Other & 0.12 & 0.10 & 0.09 \\
\hline \multicolumn{4}{|c|}{ Country of origin (ref. other Eastern European country) } \\
\hline Romania & 0.05 & -0.02 & -0.00 \\
\hline Albania & -0.09 & -0.07 & -0.03 \\
\hline Ukraine & $0.17^{*}$ & $0.15^{\star}$ & 0.09 \\
\hline Moldova & -0.04 & -0.11 & -0.11 \\
\hline Poland & $0.20^{*}$ & $0.20^{\star}$ & 0.13 \\
\hline Duration of residence & & $-0.03^{\star \star \star}$ & $-0.02^{\star \star \star}$ \\
\hline \multicolumn{4}{|l|}{ Intearation } \\
\hline Socio-cultural & & & $-0.29^{\star \star \star}$ \\
\hline Economic & & & $0.14^{* * *}$ \\
\hline Adjusted $\mathrm{R}^{2}$ & 0.156 & 0.174 & 0.254 \\
\hline
\end{tabular}

${ }^{* \star *} p<.001 ;{ }^{* *} p<.01 ;{ }^{*} p<.05$

Source: Integrometro Survey 